\title{
ANALISA KINERJA IDSL/PUMMA UNTUK PERINGATAN DINI TSUNAMI DI PANGANDARAN
}

\section{MAPPING OF BENTHIC HABITATS ON CORAL REEF ECOSYSTEM IN MENJANGAN ISLAND}

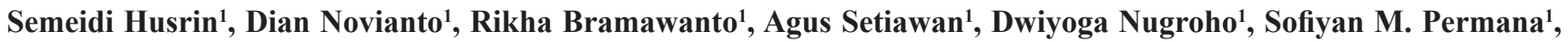
Agus Sufyan ${ }^{1}$, Sarnanda1, Daud SA. Sianturi' ${ }^{1}$, Usep Mulyadi', Donal Daniel', Ifan Ridlo Suhelmi ${ }^{1}$, Muchammad S.B Purnama ${ }^{2}$

\author{
${ }^{1}$ Pusat Riset Kelautan, BRSDMKP-KKP \\ Gedung BRSDMKP 2, Jl. Pasir Putih II, Ancol - Jakarta Utara 14430 \\ Tel./Fax.: +62-21-647-00-755 ext.3118/+62-21-647-11-654, Email: s.husrin@kkp.go.id \\ ${ }^{2}$ Program Studi Ilmu Kelautan, Fakultas Perikanan dan Ilmu Kelautan, Universitas Pajajaran - \\ J1. Raya Bandung Sumedang Km.21, Jatinangor - Sumedang 45363 \\ e-mail : s.husrin@kkp.go.id
}

Diterima tanggal: 17 Maret 2021 ; diterima setelah perbaikan: 26 Agutus 2021; Disetujui tanggal: 26 Agustus 2021

\begin{abstract}
ABSTRAK
Salah satu alat untuk peringatan dini tsunami, IDSL (Inexpensive Device for Sea Level Measurement) atau PUMMA (Perangkat Ukur Murah untuk Muka Air laut) yang merupakan sebuat stasiun pasang surut real-time telah terpasang di Pantai Pangandaran sejak Oktober 2019. Tulisan ini bertujuan untuk menganalisa kinerja IDSL/PUMMA berdasarkan parameter-parameter penting untuk peringatan dini tsunami seperti kerapatan data, kecepatan transmisi data, kualitas gambar CCTV camera, dan kemampuan memberikan peringatan dini itu sendiri. Data selama 9 bulan pertama berhasil dianalisa berdasarkan parameter-parameter tersebut diperkuat dengan pemodelan tsunami di Selatan Jawa menggunakan model numrik COMCOT. Hasil analisa memperlihatkan bahwa IDSL/PUMMA bekerja dengan baik dengan memberikan data valid dengan kerapatan setiap 10 detik sebanyak lebih dari 91\% dengan kecepatan transmisi data di bawah 25 detik (99\%). Sementara itu, gambar CCTV camera dengan kualitas baik dan sedang mencapai 69\%. Berdasarkan hasil pemodelan tsunami, deteksi langsung anomali muka air tidak dapat dilakukan kurang dari 5 menit. Namun, peringatan dini tsunami berpotensi dikeluarkan melalui guncangan atau pergerakan anjungan stasiun pasang surut yang diakibatkan oleh gempabumi. Berdasarkan hasil analisa kinerja secara keseluruhan, IDSL/PUMMA dan sistem sejenis lainnya sangat layak untuk dijadikan penguat sistem peringatan dini tsunami di Indonesia.
\end{abstract}

Kata kunci: IDSL, PUMMA, Pasang surut, TEWS, Pangandaran, Tsunami.

\section{ABSTRACT}

One of the devices for the purpose of tsunami early warning system, IDSL (Inexpensive Device for Sea Level Measurement) or locally known as PUMMA (Perangkat Ukur Murah untuk Muka Air laut), a real-time tide gauge has been installed in Pangandaran Beach since October 2019. The objective of this paper is to analyse the device's performance based on key parameters for tsunami early warning system such as data density, latency time, the quality of CCTV images, and the release of warning capabilities. All data for about 9 months were collected, analysed and compared with the tsunami characteristics numerical simulation using COMCOT model. Results show that IDSL/PUMMA collected data with time interval less than 10 seconds, produced 91\% of valid data, and maintained $99 \%$ of latency time in less than 25 seconds. For the quality of CCTV camera, good and fair images contributed for about $69 \%$. Based on the 2006 tsunami simulation, the anomaly of water surface elevation will not be able to be detected in less than 5 minutes. However, the motions of the tide gauge platform and the metal support frame of the IDSL/PUMMA due to the earthquake may provide an instant early warning. Therefore, considering those key performances, IDSL/PUMMA and other similar systems are strongly recommended to enhance the existing tsunami early warning system in Indonesia..

Keywords: IDSL, PUMMA, tide, TEWS, pangandaran, tsunami.

$\overline{\text { Analisa Kinerja IDSL/PUMMA untuk Peringatan Dini Tsunami di Pangandaran - Semeidi Husrin, Dian Novianto, Rikha }}$ Bramawanto, Agus Setiawan, Dwiyoga Nugroho, Sofiyan M. Permana, Agus Sufyan, Sarnanda, Daud S.A. Sianturi, 


\section{PENDAHULUAN}

IDSL (Inexpensive Device for Sea Level Measurement) atau PUMMA (Perangkat Ukur Murah untuk Muka Air laut) yang dilengkapi dengan sistem peringatan dini tsunami dikembangkan oleh Joint Reserach Centre The European Commission (JRC-EC) dan telah diterapkan di Laut Mediterania (Annunziato, 2015; Annunziato, et al. 2016). Sistem peringatan dini berdasarkan pasang surut dikembangkan di Laut Mediterania dengan pertimbangan aspek-aspek teknis maupun nonteknis. Aspek teknis terpenting yang menjadi pertimbangan utama dalah tsunami jarak dekat di kawsan tersebut di mana sumber tsunami dapat terjadi di suatu kawasan dan berdampak pada kawasan lainnya. Sementara itu, aspek nonteknis yang cukup kuat adalah aspek finansial di mana kejadian tsunami di kawasan ini tidak terlalu sering (Maramai, et al 2019) sehingga investasi yang minimalis tetapi cukup dapat diandalkan untuk Tsunami Early Warnng System (TEWS) sangat dibutuhkan guna menjamin keberlangsungan dari sistem ini. Berdasarkan informasi terakhir, sistem ini telah terpasang di negara-negara di Eropa, Asia dan Afrika yang berbatasan dengan Laut Mediterania dengan jumlah total 41 alat dan dapat dipantau secara rela-time melalui website IDSL JRCEC (https://webcritech.jrc.ec.europa.eu/TAD_server/ Home). Kejadian tsunami terakhir yang sempat terekam dan memberikan peringatan dini ke sistem adalah saat kejadian longsoran Gunung Stromboli di Italia pada tanggal 3 Juni 2019 yang menyebabkan tsunami kecil (JRC-EC, 2019). Kemampuan IDSL memberikan peringatan dini tsunami tidak terlepas dari kemampuan alat ini untuk merekam data dengan sangat rapat (setiap 5 detik) dan mampu mengirim data dengan sangat cepat (real-time) (Annunziato et al 2019). Berdasarakan kemampuan teknis dan aspek nonteknis tersebut di atas, IDSL/PUMMA patut diperhitungkan untuk diterapkan di Perairan Indonesia yang rentan akan bencana tsunami seperti di Pantai Pangandaran, Selatan Jawa Barat yang terakhir kali mengalami tsunami pada tahun 2006 (Husrin, et al 2015).

Aspek penting lainnya mengapa sistem IDSL layak diperhitungkan adalah pada pada sistem Indonesia Tsunami Early Warning System (Ina-TEWS) yang terlihat pada kejadian di Palu dan Selat Sunda 2018. Kejadian Tsunami Palu 2018 dan Tsunami Selat Sunda 2018 kembali memperlihatkan kelemahan sistem peringatan dini tsunami (Ina-TEWS) yang sudah dikembangkan di Indonesia selama ini (BMKG, 2019). Kejadian tsunami Palu 2018 yang diperkirakan disebabkan oleh longsoran bawah air (Omira, et al 2019; Liu et al 2020; Husrin, et al 2020a) dan tsunami Selat Sunda yang juga disebabkan oleh longsorang badan Gunung Anak Krakatau (Williams, et al., 2019; Borrerro, et al 2020) tidak terdeteksi oleh sistem TEWS eksisting yang hanya mengandalkan tsunami yang diakibatkan oleh kejadian gempabumi (Lauterjung et al 2010; BMKG, 2019). Sistem pendukung Ina-TEWS yang ada di BIG dan Kementerian ESDM juga tidak didesain untuk peringatan dini tsunami. Jaringan pasut BIG saat itu tidak realtime (bisa mencapai 10 menit) dan rentang data cukup lama (setiap 2 menit) dan jaringan sistem pemantau gunung api juga tidak didesain untuk memantau dampak letusan ke badan air di sekitarnya (Husrin, et al. 2020b). Sementara itu, bouy dari Proyek GITEWS dan BPPT yang terpasang sejak 2005 di Samudra Hindia dan Selat Sunda sudah lama tidak berfungsi (hilang dan/atau rusak) karena berbagai permasalahan baik teknis maupun nonteknis (Lauterjung, et al 2017).

Penguatan sistem peringatan dini tsunami dengan melibatkan stasiun pasang surut bukan hal baru. Sistem ini sudah termasuk ke dalam rencana besar Ina-TEWS (Lauterjung et al., 2010). Namun, dalam perjalanannya Ina-TEWS hingga saat ini masih bergantung penuh pada sistem seismometer (BMKG, 2019). Pemanfaatan stasiun pasang surut yang real-time belum optimal dilakukan dan baru direncanakan untuk dikembangankan dengan konsep Indonesia Tsunami early warning system Non Tektonik (Ina-TNT) (Husrin, et al., 2020b). Oleh karena itu, tulisan ini bertujuan untuk memberikan bukti-bukti ilmiah bahwa stasiun pasang surut layak dipertimbangkan untuk memperkuat TEWS di Indonesia dengan mengambil contoh data dari IDSL/PUMMA yang sudah terpasang di Pantai Pangandaran, Selatan Jawa Barat.

\section{BAHAN DAN METODE}

IDSL/PUMMA Pangandaran terpasang di Pantai Batu Karas $\left(-7.748359^{\circ} \mathrm{LS}\right.$ dan $\left.108.501402^{\circ} \mathrm{BT}\right)$ Pangandaran sejak 28 Oktober 2019 atas kerjasama Pusat Riset Kelautan BRSDMKP-KKP, JRC-EC, Ikatan Ahli Tsunami Indonesia (IATsI) dan Badan Informasi Geospasial (BIG). Alat tersebut dipasang pada anjungan stasiun pasang surut BIG yang berjarak sekitar $60 \mathrm{~m}$ dari garis pantai (Gambar 1). Untuk menganalisa kinerja IDSL/PUMMA untuk pemanfaatan TEWS di Pantai Pangandaran diperlukan dua tahapan pekerjaan sebagai berikut:

- Analisa data IDSL/PUMMA yang sudah terpasang sejak 28 Oktober 2019 dan seluruh data termasuk 

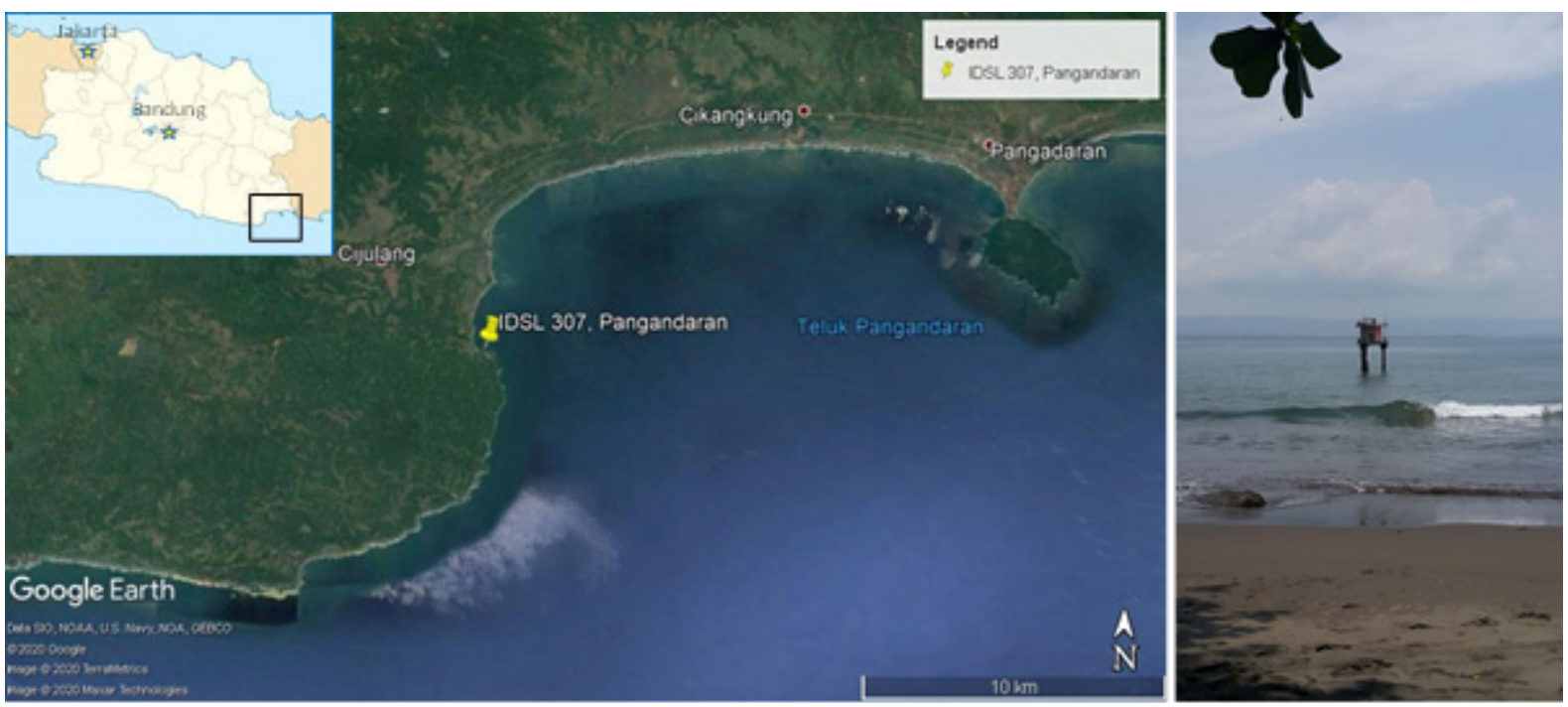

Gambar 1. a) Lokasi pemasangan IDSL/PUMMA di Pantai Batukaras, Pangandaran dan b) Anjungan stasiun BIG untuk pemasangan alat IDSL.

Figure 1. a) IDSL/PUMMA installation location at Batukaras Beach, Pangandaran and b) BIG station platform for installation of IDSL equipment.

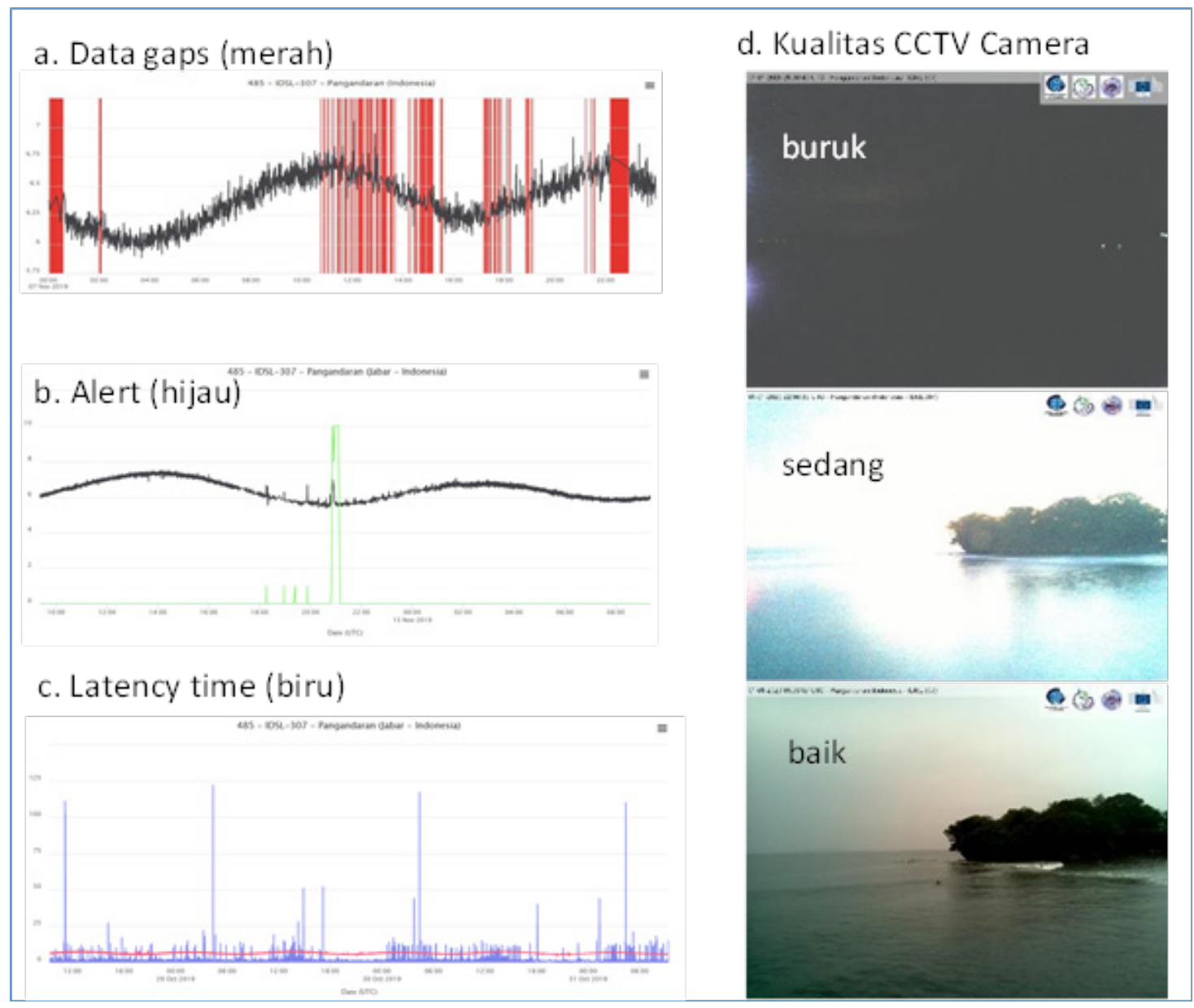

Gambar 2. Cara identifikasi data yang dapat diunduh langsung dari website IDSL a) data kosong (gaps), b) peringatan dini (alerts), c) waktu transmisi data (latency time) dan d) gambar CCTV.

Figure 2. How to identify data that can be downloaded directly from the IDSL website a) blank data (gaps), b) early warnings (alerts), c) data transmission time (latency time) and d) CCTV images.

$\overline{\text { Analisa Kinerja IDSL/PUMMA untuk Peringatan Dini Tsunami di Pangandaran - Semeidi Husrin, Dian Novianto, Rikha }}$ Bramawanto, Agus Setiawan, Dwiyoga Nugroho, Sofiyan M. Permana, Agus Sufyan, Sarnanda, Daud S.A. Sianturi, Usep Mulyadi, Donal Daniel, Ifan Ridlo Suhelmi, Muchammad S.B. Purnama 
gambar-gambar CCTV dapat diakses secara bebas pada webiste IDSL di https://webcritech.jrc. ec.europa.eu/TAD_server/Device/485. Data IDSL/ PUMMA berhasil dinduh dalam rentang kurang lebih 9 bulan dari tanggal 28 Oktober 2019 hingga 12 Juli 2020 dan dapat langsung dianalisa dengan bantuan visual website IDSL atau dengan Microsoft Excel dan sejenisnya. Analisa data IDSL/PUMMA meliputi analisa statistik berupa analisa data gap (data kosong) (Gambar 2a), analisa statistik kecepatan transmisi data kurang dari 30 detik (latency time) (Gambar 2b), analisa statistik kualitas gambar CCTV yang dibagi ke dalam 3 kategori (jelek, sedang dan bagus) (Gambar 2d) dan analisa statistik sistem peringatan dini (Gambar 2c). Analisa karakteristk pasang surut tidak didiskusikan di sini karena sudah dibahas dengan sangat rinci dengan membandingkan dengan data dari stasiun pasut BIG dan alat tidemaster dari Valeport yang dipasang oleh Pusat Riset Kelautan (Husrin et al 2020b).

- Analisa pemodelan pembentukan dan perambatan gelombang tsunami di Selatan Jawa berdasarkan kejadian tsunami tahun 2006. Pemodelan tsunami diperlukan untuk memastikan apakah IDSL dapat mendeteksi anomali muka air yang terjadi sesaat setelah kejadian tsunami. Fenomena surut air laut sesaat setelah gempabumi perlu dianalisa dari sisi waktu apakah dapat dideteksi dalam kurun waktu kurang dari 5 menit pasca kejadian gempa bumi. Pemodelan tsunami mengacu ke berbagai parameter dari publikasi tentang tsunami Pangandaran 2006 (Hermann et al., 2007; Lavigne et al., 2007). Model COMCOT (Wang, 2009) digunakan untuk mensimulasikan kejadian tsunami 2006 dengan validasi model mengacu ke Husrin et al., (2015).
Berdasarkan hasil-hasil analisa di atas, kelayakan IDSL/PUMMA untuk dimanfaatkan sebagai TEWS di Selatan Jawa dapat dilakukan dengan mengacu pada standar peringatan dini tsunami BMKG yaitu mampu memberikan peringatan dini dalam kurun waktu kurang dari 5 menit dan terdapat cukup waktu bagi warga pesisir untuk menyelematkan diri ke tempattempat yang aman (BMKG, 2010).

\section{HASIL DAN PEMBAHASAN}

\section{Data IDSL/PUMMA}

Data yang berhasil didownload pada penelitian ini adalah pada rentang 28 Oktober 2019 hingga 30 Juni 2020 atau 247 hari dengan total jumlah data yang berhasil didownload berjumlah 1.874 .880 data. Data mentah IDSL memiliki data sebanyak satu data per 5-12 detik (terdapat variasi yang tidak tetap), sedangkan data visual memiliki 1 data setiap 15 menit, meski pada Januari 2020 hanya terdapat 1 data setiap jamnya. Pada bulan Januari 2020, rentang waktu pengambilan gambar CCTV setiap jam sengaja dilakukan dalam rangka menguji konsumsi data internet. Hasil pengumpulan data dan pengelompokkan data yang terekam dan yang hilang, maka dapat diidentifikasi secara statistik data IDSL/PUMMA yang hilang (data gaps). Meski dirancang untuk mengambil data sebanyak 5-12 kali dalam satu menit, IDSL seringkali mengambil data lebih jarang. Hal ini disebabkan oleh beberapa faktor seperti kualitas sensor, kapasitas memori acak, dan kualitas sinyal yang digunakan alat untuk transfer data. Tabel 1 memperlihatkan rangkuman dari data IDSL/ PUMMA yang hilang atau tidak terekam (data gaps).

Dilihat dari tabel 1, gaps paling banyak terjadi pada november dan paling sedikit pada Oktober, yang hanya

Tabel 1. Luasan sebaran sedimentasi

Table 1. Extent of Sedimentation Distribution

\begin{tabular}{|c|c|c|c|c|c|c|}
\hline Parameter & $\begin{array}{l}\text { Total durasi gaps } \\
\text { (hari:jam:mnt:dtk) }\end{array}$ & gaps & $\begin{array}{l}\text { Jumlah Rata-rat } \\
\text { (jam:mnt:dtk) }\end{array}$ & $\begin{array}{l}\text { ita gaps Maks. } \\
\text { (jam:mnt:dtk) }\end{array}$ & $\begin{array}{l}\text { Min. } \\
\text { (jam:mnt:dtk) }\end{array}$ & $\begin{array}{l}\text { Latency time } \\
>25 \mathrm{det}\end{array}$ \\
\hline Okt.19 & $00: 11: 46: 04$ & 430 & 0:01:39 & $1: 00: 51$ & $0: 00: 10$ & 14 \\
\hline Nov.19 & 08:06:09:54 & 2972 & 0:04:00 & $23: 59: 59$ & $0: 00: 12$ & 113 \\
\hline Des.19 & $07: 14: 33: 33$ & 2721 & 0:04:07 & $23: 59: 59$ & $0: 00: 12$ & 5843 \\
\hline $\operatorname{Jan} .20$ & 01:18:42:02 & 2333 & 0:01:06 & $2: 06: 56$ & 0:00:11 & 151 \\
\hline Feb.20 & $02: 12: 06: 44$ & 1466 & $0: 02: 28$ & $14: 19: 46$ & $0: 00: 27$ & 36 \\
\hline Mar.20 & $01: 14: 24: 54$ & 1691 & $0: 08: 14$ & $23: 59: 59$ & $0: 00: 31$ & 1417 \\
\hline Apr.20 & $04: 17: 49: 26$ & 1278 & $0: 11: 19$ & $23: 59: 59$ & $0: 00: 31$ & 135 \\
\hline Mei.20 & $02: 17: 58: 04$ & 263 & $0: 15: 03$ & $5: 35: 56$ & $0: 00: 22$ & 15 \\
\hline Jun.20 & 01:01:20:29 & 43 & $0: 35: 22$ & $17: 08: 40$ & $0: 00: 35$ & 12 \\
\hline Total & $30: 18: 51: 10$ & 13197 & $0: 03: 22$ & $23: 59: 59$ & 0:00:10 & 7736 \\
\hline
\end{tabular}




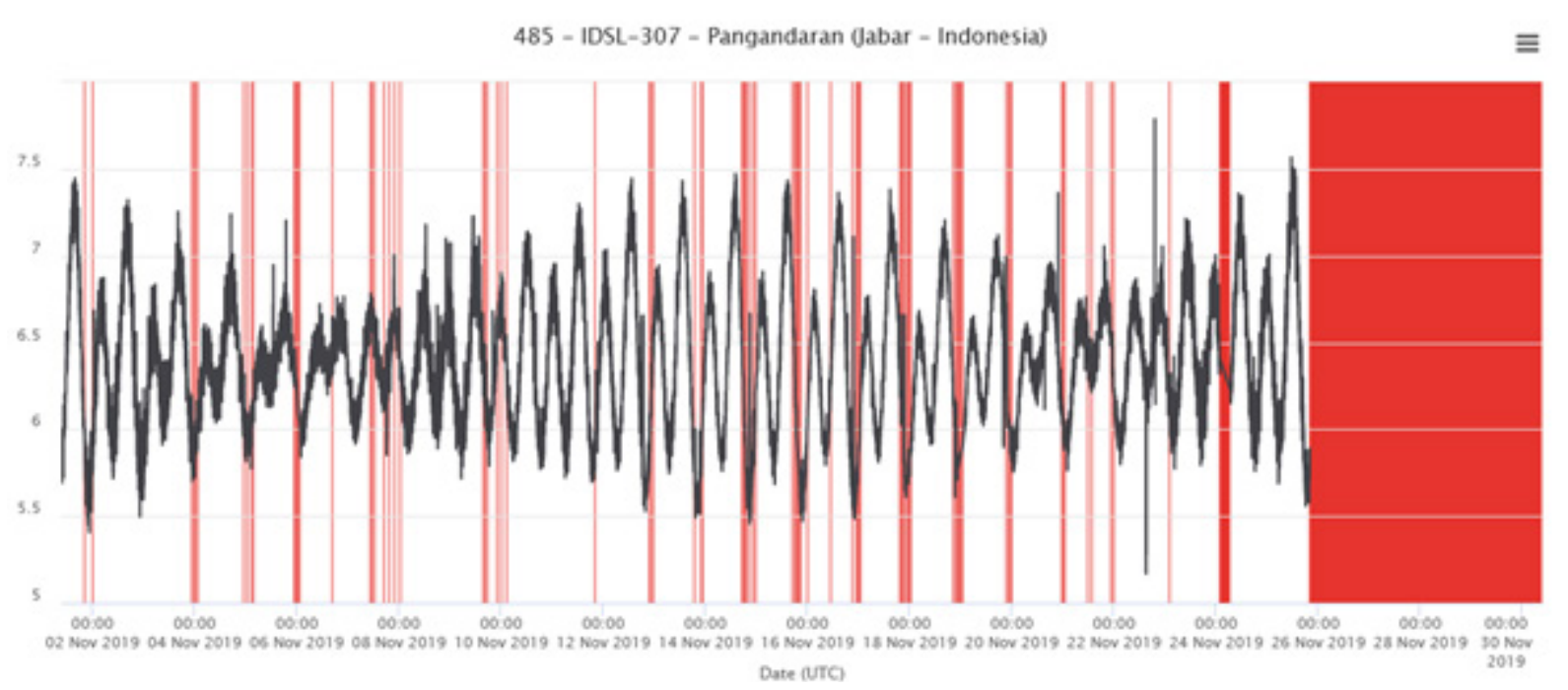

Gambar 3. Gaps data (warna merah) yang cukup lama di akhir bulan November 2019 yang diakibatkan oleh kesalahan nonteknis

Figure 3. Long data gaps (red color) at the end of November 2019 caused by non-technical errors

memiliki data selama 4 hari, disusul dengan bulan Juni. Pada bulan Mei terjadi perbaikan IDSL dimana sensor lama diganti dengan sensor baru dan hasilnya terlihat signifikan dimana pada bulan Juni hanya terjadi 43 kali gaps. Gaps paling singkat yang terdeteksi terjadi pada bulan Oktober dengan durasi hanya 10 detik saja. Sedangkan paling lama tercatat berlangsung selama berturut-turut dari 25 November sampai dengan 2 Desember 2019 (Gambar 4). Gaps ini terjadi akibat adanya kesalahan non-teknis dalam pembelian paket internet sehingga pengiriman data ke server tidak terjadi.

Dalam tabel 1 dapat dilihat total dari keseluruhan Gaps mencapai 30 Hari 18 Jam 51 Menit 10 detik. Jika dibandingkan dengan keseluruhan waktu IDSL mengambil data maka akan diperoleh persentase data kosong atau gaps sebesar $12,14 \%$, yang berarti $87,85 \%$ data berhasil dicatat oleh IDSL dengan kerapatan data di bawah 10 detik. Nilai ini akan semakin besar jika saja faktor nonteknis yang terjadi pada akhir bulan November 2019 tidak dimasukkan dalam perhitungan. Nilai data kosong menjadi $\sim 22$ hari yang artinya prosentase data kosong menjadi $9 \%$ atau dengan kata lain data yang valid mencapai $91 \%$. Rata-rata durasi terjadinya gaps dalam satu hari mencapai 2 jam 59 menit 29 detik ( $\sim 3$ jam per hari). Durasi rata-rata per hari ini tentu cukup tinggi mengingat kejadian tsunami dapat terjadi di rentang waktu 3 jam tersebut. Tetapi jika dilihat dari rata-rata durasi gaps per data count, IDSL masih menunjukkan performa yang baik dengan waktu 3 menit 22 detik gaps tiap terjadinya gaps, artinya di luar kejadian kesalahan pembelian paket data dan kerusakan pada sensor yang terjadi pada bulan April-Mei, data gaps pada IDSL sangat sedikit dan dalam rentang kurang 3 menit per hari.

Kehilangan data atau gaps terkadang terkait erat dengan waktu trasmisi data dari alat ke server atau dikenal dengan istilah latency time atau waktu jeda. Latency time pada IDSL dapat dianalisa secara visual langsung di website IDSL. Berdasarkan data yang berhasil diunduh (Tabel 1) maka dapat disimpulkan bahwa latency time untuk IDSL lebih dari 25 detik adalah berjumlah 7736 data atau sekitar $0,4 \%$ dari total data IDSL yang berjumlah 1874880 data. Dengan kata lain, latency time dari IDSL Pangandaran yang kurang dari 25 detik mencapai 99,6\%.

Aspek penting lainnya dari data IDSL/PUMMA adalah peringatan dini (alert) yang secara otomatis dikeluarkan oleh server dan diterima oleh email atau sms yang sudah ditentukan. Peringatan dini atau alert ini bekerja jika terjadi anomali atau kelainan pada muka air. IDSL mengadopsi metoda Kalman Filters (Annunziato, 2015) untuk melakukan prediksi pergerakan muka air dan akan memberikan peringatan jika standar deviasi dari prediksi data melampaui batasan (treshold) level 1 hingga 10. Peringatan akan dikeluarkan jika batasan standar deviasi lebih besar dari 5 tercapai. Informasi lebih rinci mengenai teknis peringatan dini dan algoritma Kalman filter yang dipergunakan dapat dilihat di Annunziato, et al (2016). Peringatan dini yang dikeluarkan oleh IDSL/PUMMA juga dapat diakses dan diunduh langsung dari website IDSL. 


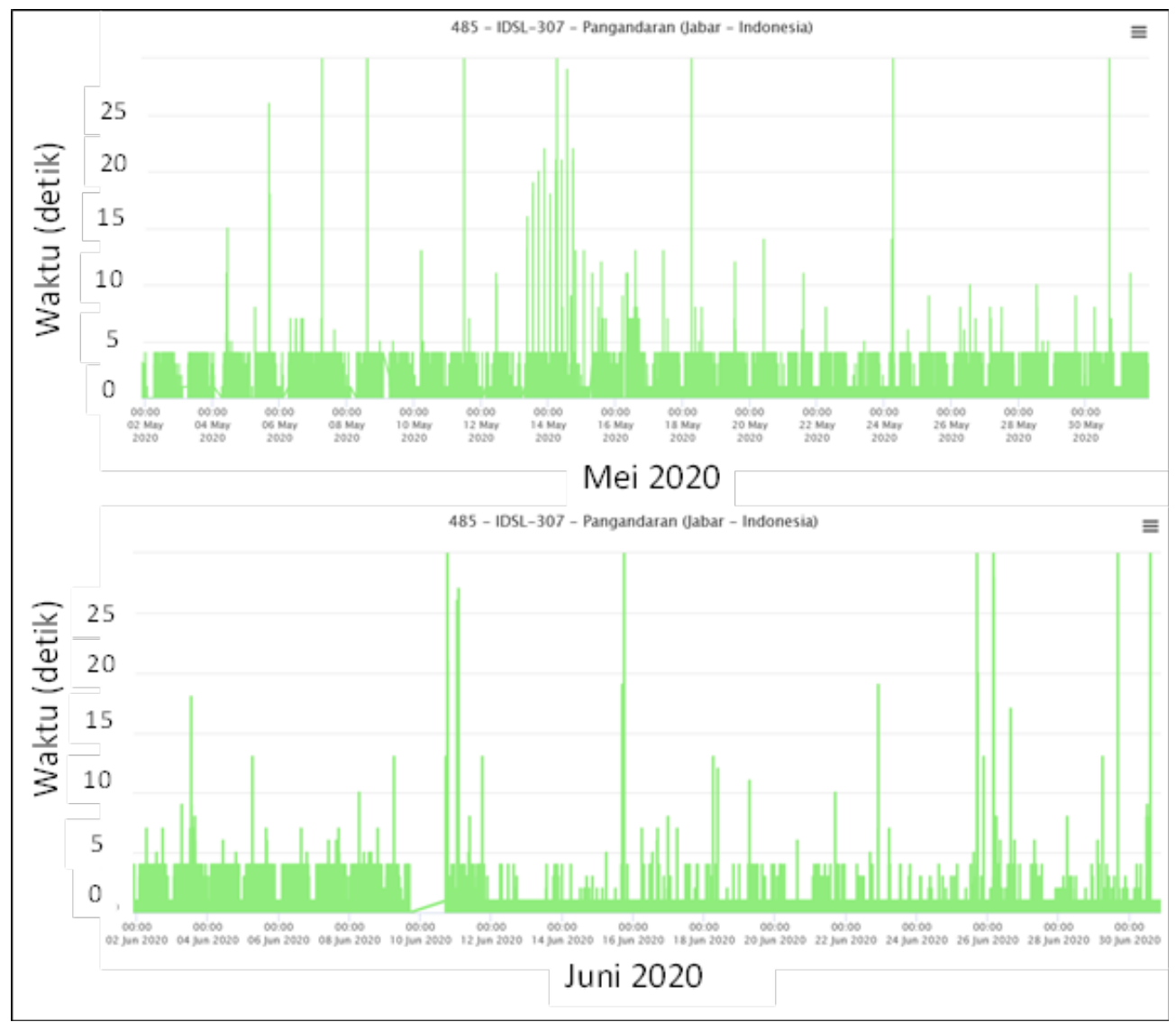

Gambar 3. Gaps data (warna merah) yang cukup lama di akhir bulan November 2019 yang diakibatkan oleh kesalahan nonteknis

Figure 3. Long data gaps (red color) at the end of November 2019 caused by non-technical errors

Gambar 5 memperlihatkan peringatan dini(alerts) yang dikeluarkan oleh IDSL selama pengamatan. Selama rentang pengamatan peringatan yang dikeluarkan sistem berjumlah 393 di mana peringatan terbanyak terjadi pada Juni 2020 dan paling sedikit terjadi pada Januari 2020. Sementara itu, skala peringatan dini terbanyak berada pada level 1 dengan 120 kejadian dan paling sedikit berada pada level 9 dengan 9 kejadian. Level 10 yang merupakan level tertinggi tercatat sebanyak 35 kali. Seluruh peringatan yang diterima bukan kejadian tsunami karena pada rentang waktu ini berdasarkan data dari USGS earthquake Catalogue (https://earthquake.usgs.gov/) tidak terjadi kejadian gempa bumi dengan kekuatan melebihi Mw 6. Peringatan yang diterima oleh IDSL/PUMMA dipastikan diakibatkan oleh berbagai aspek sebagai berikut:

- Aktivitas warga yang berwisata di Pantai Batu karas seperti berselancar, berenang, memancing dan memarkir perahu di sekitar anjungan stasiun pasang surut seringkali mendekati bahkan berada persis di bawah sensor IDSL/PUMMA sehingga alat langsung mencatat adanya anomali muka air dan memberikan peringatan dini ke sistem.
- Saat cuaca buruk menyebabkan kondisi perairan dangkal di sekitar anjungan menjadi sangat bergelombang dan air hujan yang sangat lebat menyebabkan bacaan sensor terganggu. Hal ini berakibat pada sensor yang membaca air hujan yang begitu lebat dan limpasan/cipratan air sebagai anomali muka air sehingga peringatan pun dikeluarkan. Hal ini bisa dipantau langsung dari CCTV yang terpasang pada IDSL.

Selain data yang rapat, transmisi yang cepat (latency time), kemampuan mengeluarkan alert (peringatan dini), IDSL/PUMMA juga dilengkapi dengan kamera CCTV yang mampu menangkap gambar 15 menit sekali saat kondisi normal dan 1 menit sekali saat peringatan dini aktif. Sepanjang pengamatan, terdapat 20.130 foto CCTV yang dapat dianalisa secara visual dan dikelompokkan ke dalam kategori buruk, sedang dan baik. Dari total gambar CCTV tersebut terdapat sebanyak $31 \%$ termasuk kategori buruk dimana gambar gelap gulita (malam hari), putih (peralihan pagi-siang dan peralihan sore-malam) atau ketika kondisi badai. Untuk gambar kategori sedang di mana rona lingkungan masih bisa dikenali memiliki 


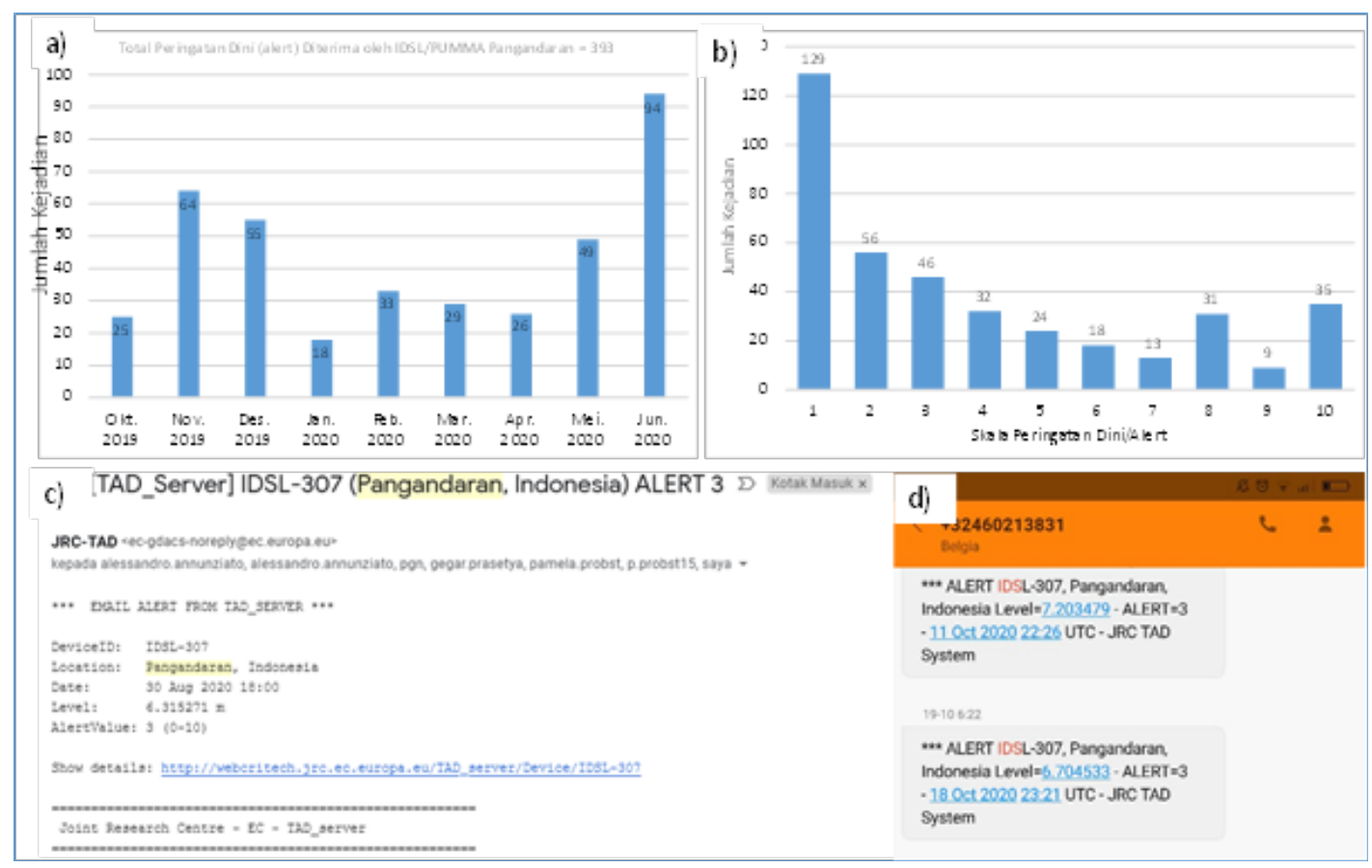

Gambar 5. a) Peringatan dini/alerts yang dikeluarkan oleh alat setiap bulannya, b) Distribusi level peringatan dini, c) Peringatan yang diterima di email dan d) Peringatan dini yang diterima di SMS

Figure 5. a) Early warnings/alerts issued by the device every month, b) Distribution of early warning levels, c) Warnings received by email and d) Early warnings received by SMS

prosentase sebanyak sebanyak $40 \%$ dan kategori baik di mana seluruh objek dapat dikenali dengan jelas sebanyak $29 \%$. Berdasarkan pengamatan maka dapat disimpulkan bahwa total prosentase gambar dengan kategori sedang dan baik masih dapat diandalkan untuk mengkonfirmasi apakah tsunami betul-betul terjadi atau tidak dengan total mencapai $69 \%$.

\section{Pemodelan Tsunami untuk Pangandaran}

Kejadian tsunami pada tanggal 17 Juli 2006 dimodelkan kembali untuk melihat potensi deteksi dini perubahan muka air di pesisir muka air dalam kurun waktu kurang dari 5 menit. Tsunami Pangandaran 2006 diakibatkan oleh gempa bumi berkekuatan $7.95 \mathrm{Mw}$ dengan karakteristik gempabumi berdasarkan Husrin, et al. (2015). Karakteristik gempa bumi sebagai parameter sumber tsunami kemudian dimodelkan menggunakan model opensource berbasis persamaan nonlinear air dangkal atau shallow water nonlinear equation (NLSWE), COMCOT versi 1.7 (Wang, 2009). Berdasarkan pemodelan yang divalidasi dengan data dari Lavigne, et al (2007) didapatkan bahwa karakteristik tsunami di Pangandaran dan sekitarnya adalah sebagai berikut:

- Kedatangan tsunami didahului oleh surutnya air laut. Hal ini sesuai dengan temuan di lapangan (Gambar 6).

- Tsunami melaju lebih cepat di perairan dalam dan melambat di perairan dangkal namun tinggi gelombang makin tinggi (shoalling)

- Gelombang pertama tsunami mencapai pesisir Pangandaran antara 45-60 menit, tergantung lokasinya. Hasil simulasi ini sesuai dengan saksi mata dan bukti-bukti di lapangan yang menyebutkan bahwa tsunami tiba di pantai Pangandaran kurang lebih 1 jam setelah gempa bumi (Lavigne, et al. 2007).

- Gelombang tsunami yang kedua menghantam pesisir pangandaran sekitar 15-20 menit setelah gelombang pertama. Temuan ini sesuai dengan kesaksian korban tsunami di mana gelombang tsunami yang kedua merupakan gelombang yang paling merusak.

- Bentukan lahan, batimetri dan topografi terlihat cukup dominan dalam menentukan tinggi gelombang tsunami di suatu lokasi (difraksi dan refraksi gelombang) (Husrin, et al. 2015).

Penyelidikan lebih detail diperlukan untuk melihat sejauh mana elevasi muka air menunjukan anomalinya dan dapat memicu peringatan dini pada alat IDSL. Oleh karena itu, titik pengamatan di dekat Pantai Batu Karas $\left(-7.748359^{\circ} \mathrm{LS}\right.$ dan $\left.108.501402^{\circ} \mathrm{BT}\right)$ diambil untuk melihat kapan dan seberapa besar muka air mengalami perubahan drastis. Pemodelan tsunami di perairan Pangandaran memperlihatkan bahwa segera setelah kejadian gempabumi, perairan di Pangandaran "tertarik" ke arah laut sebagai dampak dari pergerakan 

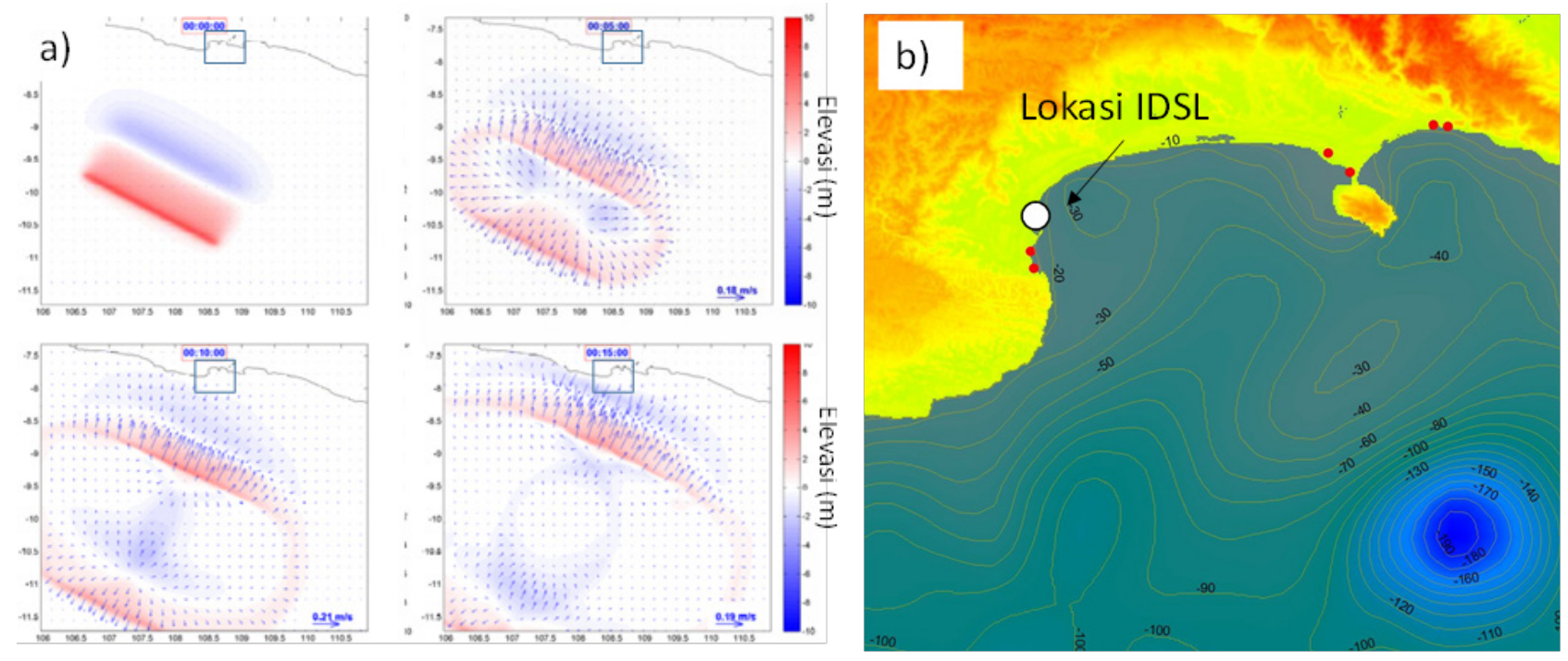

Gambar 6. a) Kejadian tsunami Pangandaran 2006 didahului oleh surut air laut setelah gempabumi dan b) Kondisi perairan dan lokasi IDSL untuk penyelidikan waktu tiba tsunami.

Figure 6. a) The 2006 Pangandaran tsunami was preceded by low tide after the earthquake and b) Water conditions and IDSL locations for tsunami arrival time investigations.

lempeng yang terjadi di sumber gempabumi. Namun, pergerakan ini terlihat cukup kecil di menit ke-5 pasca gempa bumi dan baru terlihat cukup signifikan setelah mendekati menit ke 20 (Gambar 7). Hal ini, memperlihatkan bahwa jika hanya elevasi muka air yang diandalkan, maka IDSL tidak akan daat memberikan peringatan dini di bawah 5 menit karena waktu yang dibutuhkan mendekati 20 menit pasca kejadian gempabumi. Data hasil pemodelan memperlihatkan bahwa permukaan air akan mulai mengalami anomali yang cukup signifikan pada detik ke 1.298 detik atau 21,6 menit setelah kejadian tsunami dengan kecepatan arus yang mengarah ke laut lepas melebihi $20 \mathrm{~cm} /$ detik (Gambar 7 dan Gambar 8). Pada kondisi ini di menit ke 21,6 setelah gempabumi, muka air mengalami anomali 100\% dibanding kondisi awal. Terdapat kemungkinan IDSL akan mendeteksi lebih awal karena perubahan yang terjadi di menit ke-10 setelah gempabumi, anomali muka air tercatat sebesar $31 \%$ dibanding kondisi awal (Gambar 9).

\section{IDSL Untuk Peringatan Dini Tsunami di Pangandaran}

Berdasarkan diskusi di atas dan dengan mempertimbangkan parameter-parameter yang sangat menentukan dalam sistem peringatan dini tsunami, IDSL/PUMMA atau sistem sejenis layak dimanfaatkan untuk memperkuat sistem peringatan dini tsunami di Pangandaran. Aspek-aspek seperti kerapatan data dan kecepatan transfer data dari alat ke server menjadi pertimbangan utama selain kemampuan tambahan seperti mampu memberikan peringatan dini ke email dan telefon genggam serta menampilkan gambar lingkungan pesisir melalui camera CCTV yang aktif dan dapat diakses secara bebas. Beberapa aspek berikut ini perlu mendapat pertimbangan dalam rangka peningkatan kinerja dalam pemanfaatan IDSL/ PUMMA atau sistem sejenis ke dalam sistem peringatan dini tsunami di Pantai Pangandaran dan Pantai Selatan Jawa pada umumnya:

- Pantai Pangandaran dan pantai Selatan Jawa pada umumya memiliki karakteristik tsunami yang didahului oleh gempa bumi yang tidak terlalu terasa besar namun mampu membangkitkan tsunami cukup besar di pantai. Fenomena ini dikenal dengan istilah tsunami earthquake dan terjadi beberapa kali di Selatan Jawa (Lavigne, et al., 2007; Okal, 2012; Fritz et al., 2007).

- Walau data yang valid cukup tinggi yakni mencapai 91\%, masih terdapat beberapa hal teknis yang perlu ditingkatkan sehingga kinerja data yang valid bisa mencapai $100 \%$. Hal ini dapat ditingkatkan dengan cara otomatisasi ketersediaan data internet dan stabilitas jaringan komunikasi yang dipergunakan secara umum. Masalah kestabilan sistem komunikasi data dan ketersediaan energi listrik saat bencana menjadi permasalahan utama tidak hanya pada IDSL/ PUMMA tetapi juga pada sistem lainnya dalam InaTEWS (Lauterjung, et al. 2010).

- Waktu jeda atau latency time dari alat ke server adalah hal yang sangat penting. Oleh karena itu, aspek ini perlu dijaga terus kinerjanya. Saat ini, IDSL/ PUMMA terbukti mampu menampilkan kinerja yang sangat baik dengan latency time di bawah 25 

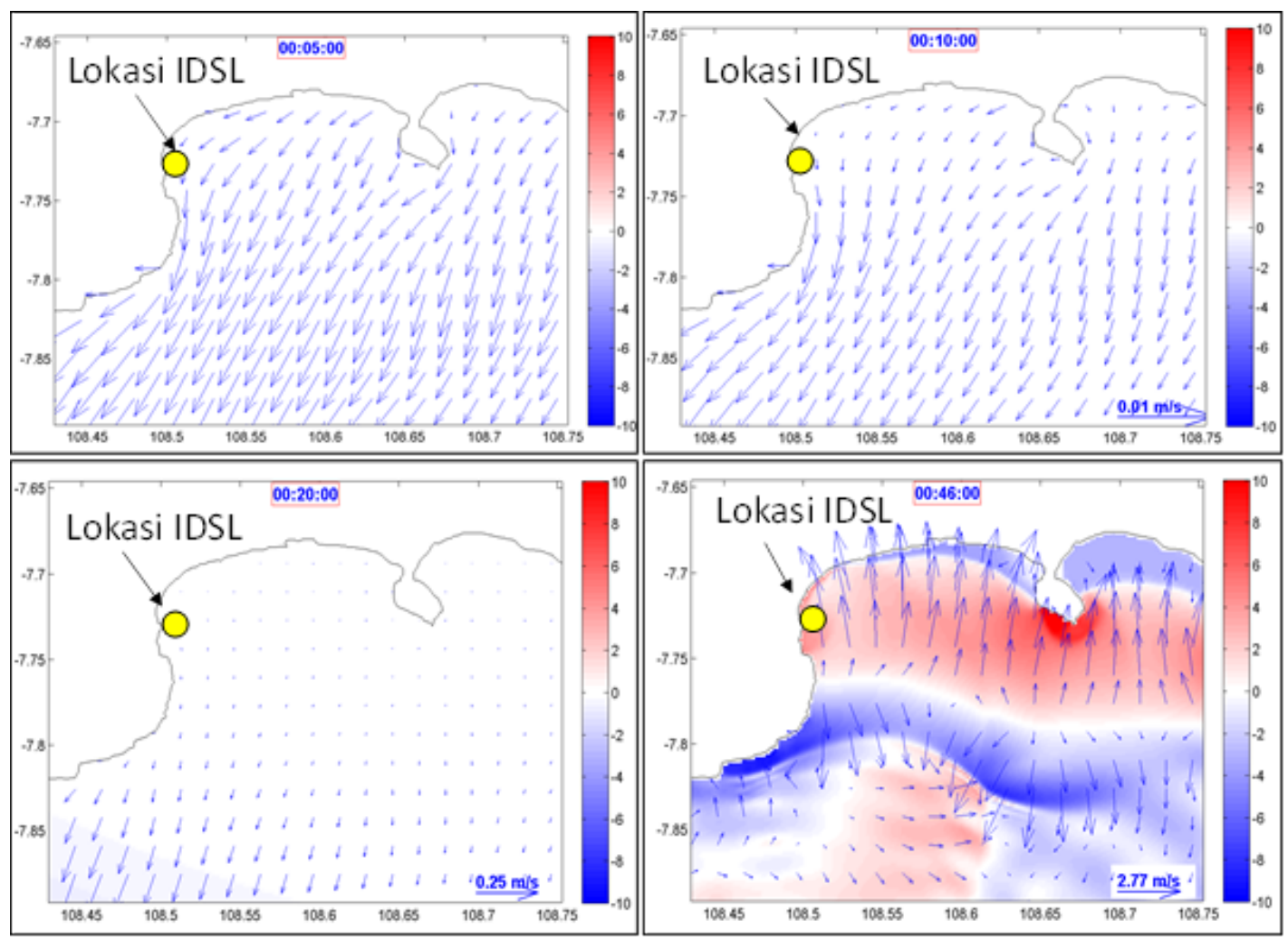

Gambar 7. Kejadian tsunami di perairan Pantai Pangandaran pada 17 Juli 2006 pada menit ke-5, 1020 dan 46 (hasil pemodelan).

Figure 7. The occurrence of a tsunami in the waters of Pangandaran Beach on July 17, 2006 at the 5th, 10th, 20th and 46th minutes (modelling results).

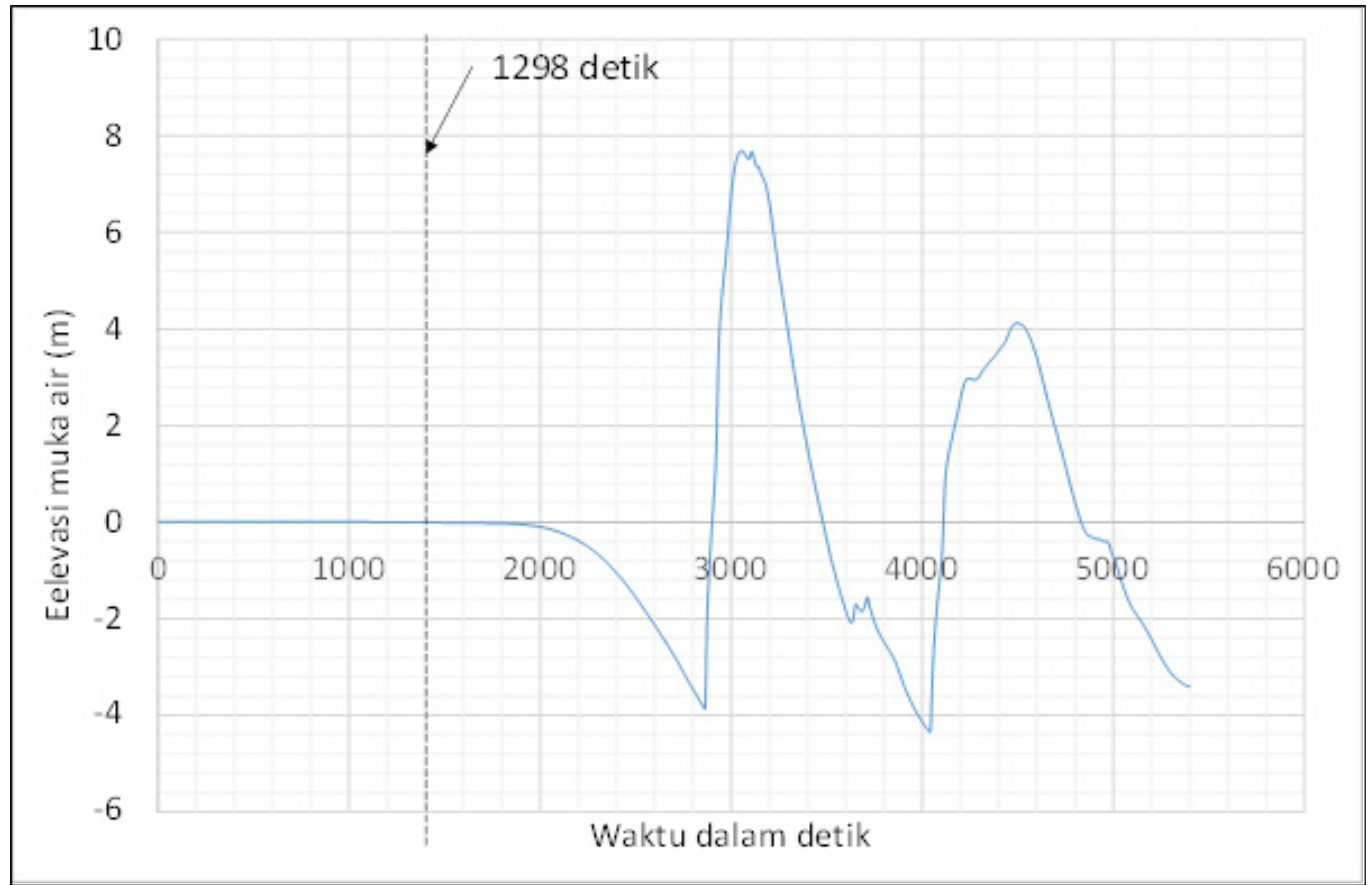

Gambar 8. Elevasi muka air hasil pemodelan di sekitar lokasi IDSL saat kejadian tsunami Pangandaran 2006.

Figure 8. Modeled water level elevation around the IDSL location during the 2006 Pangandaran tsunami. 


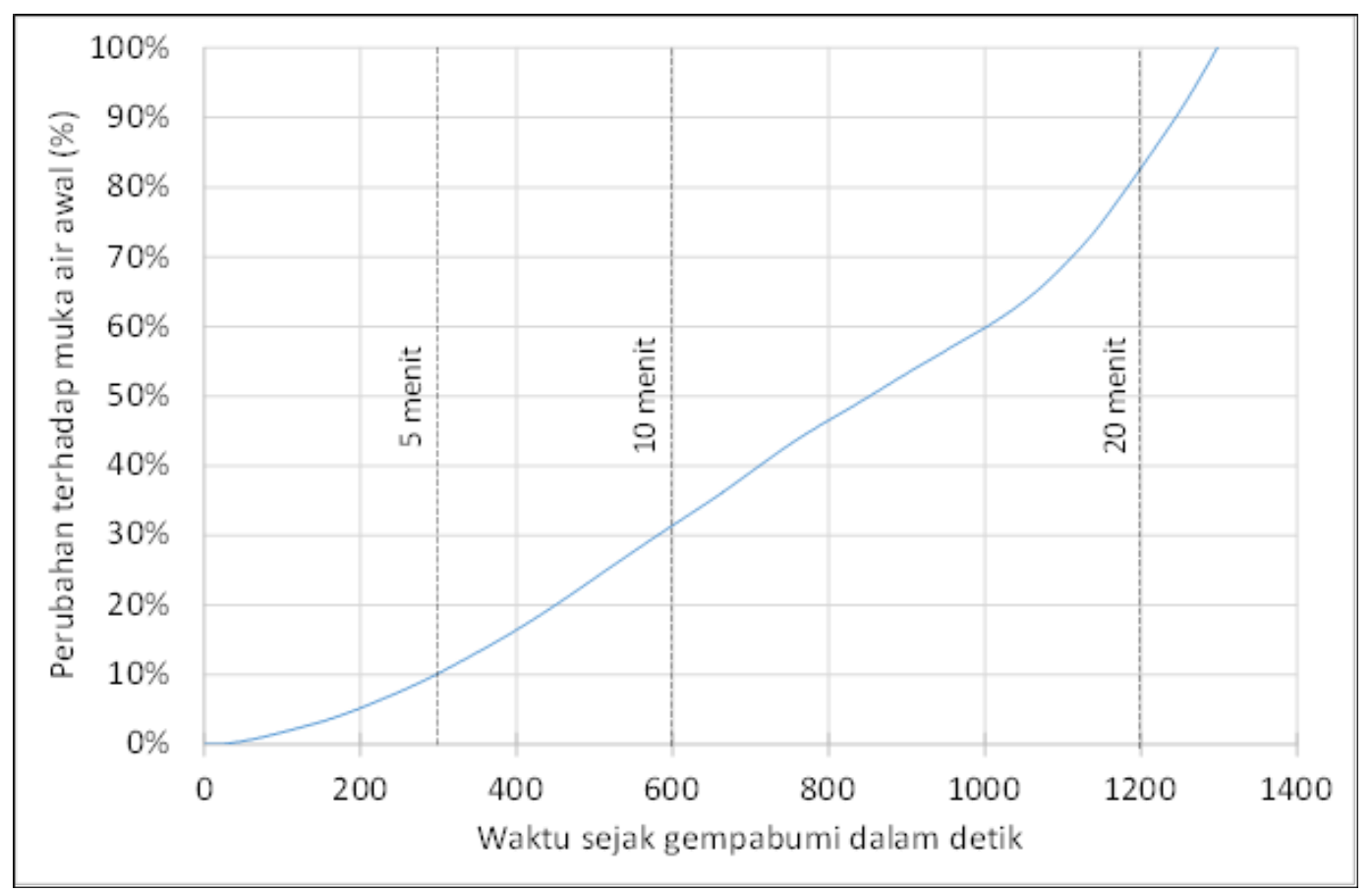

Gambar 9. Deteksi perubahan muka air selama 20 menit pertama pasca kejadian gempabumi Figure 9. Detection of changes in water level during the first 20 minutes after the earthquake

detik (real-time) sebesar 99\%. Saat ini, Seismometer BMKG yang menjadi tulang punggung Ina-TEWS juga sudah real-time (Lauterjung et al 2010; BMKG, 2019). Jaringan stasiun pasang surut BIG yang berjumlah 170 juga berhasil dibuat menjadi realtime sejak awal tahun 2020 (Husrin, et al., 2020b)

- Kualitas gambar CCTV yang dapat dikenali dengan baik dan dengan kualitas sedang mencapai $69 \%$. Artinya masih ada kemungkinan kondisi lingkungan tidak dapat dikenali terutama pada saat malam hari atau saat cuaca buruk. Hal ini tentu saja bergantung pada pencahayaan di daerah pengamatan. Pemasangan penerangan yang cukup di daerah pengamatan akan membantu proses pengamatan di malam hari sehingga akan meningkatkan kinerja CCTV Camera IDSL/PUMMA ke depan.

- Deteksi awal anomali muka air menjadi tantangan tersendiri sistem IDSL/PUMMA karena anomali muka air baru akan terjadi secara signifikan setelah menit ke 20 pasca gempabumi walaupun IDSL memiliki kemampuan mendeteksi anomali lebih awal dari itu. Namun demikian, asumsi ini belum memasukkan potensi pergerakan atau perubahan elevasi di anjungan stasiun pasut atau di darat akibat gempabumi yang terjadi. Berdasarkan catatan IDSL/PUMMA selama pengamatan, gangguan pada struktur IDSL/PUMMA yang diakibatkan oleh cuaca buruk seperti angin kencang sudah cukup untuk menyebabkan pembacaan sensor mendeteksi adanya muka air "anomali" yang bukan diakibatkan oleh anomali muka air sesungguhnya melainkan lebih ke pergerakan dari struktur rangka besi dari sensor IDSL/PUMMA itu sendiri. Pergerakan dari struktur ini menyebabkan "loncatan" data yang mengakibatkan sistem mengeluarkan peringatan dini lebih awal (Husrin, et al., 2020b). Oleh karena itu, IDSL/PUMMA berpeluang besar memberikan peringatan dini sesaat setelah kejadian gempa bumi yang diakibatkan oleh pergeseran atau pergerakan anjungan stasiun pasut IDSL/PUMMA akibat gempa bumi.

- Kehandalan dari IDSL/PUMMA memperlihatkan bahwa sistem ini sangat layak ditempatkan di perairan Indonesia lainnya, terlebih yang memiliki daratan di dekat sumber tsunami seperti Gunung Anak Krakatau (Williams, et al., 2019; Annunziato, et al., 2019) dan Pesisir Barat Sumatera dengan Kepulauan Mentawai-nya (Borrero, et al 2011). Dengan operasional dan biaya modal yang jauh lebih murah, sistem ini sangat mampu untuk diandalkan guna memperkuat Ina-TEWS atau Ina-TNT di masa yang akan datang.

- Biaya merupakan faktor yang sangat penting dalam operasional sistem peringatan dini tsunami di Indonesia. Salah satu faktor utama tidak beroperasinya jaringan bouy tsunami di Barat Sumatera adalah faktor biaya yang sangat mahal (Lauterjung, et al. 2017). Husrin et al (2020b) membandingkan faktor biaya antara IDSL/PUMMA, Bouy tsunami, Radar tsunami dan Kabel Tsunami. Dengan tetap menjaga 
kehandalannya sebagai alat deteksi awal tsunami, IDSL/PUMMA memberikan biaya modal dan operasional yang jauh lebih murah dibanding sistem lainnya. Sebagai acuan, satu bouy tsunami setara dengan 100 unit IDSL/PUMMA. Hal ini sangat penting mengingat Indonesia memiliki daerah yang begitu luas untuk dimonitor secara terus-menerus dan kejadian tsunami bisa terjadi kapan saja dan di mana saja. Oleh karena itu, faktor biaya sangat penting untuk menjamin keberlangsungan sistem peringatan dini tsunami di Indonesia.

\section{KESIMPULAN DAN SARAN}

PKinerja IDSL (Inexpensive Device for Sea Level Measurement) atau PUMMA (Perangkat Ukur Murah untuk Muka Air laut) yang dipasang oleh tim peneliti dari JRC-EC dan Pusat Riset Kelautan - BRSDMKPKKP telah berhasil dianalisa berdasarakan data yang berhasil diunduh selama 9 bulan dari Oktober 2019 hingga Juni 2020. Berdasarkan parameter-parameter kunci dalam kerangka peringatan dini tsunami maka dapat disimpulkan bahwa IDSL/PUMMA sangat layak untuk diperhitungkan sebagai penguat sistem peringatan dini tsunami di Selatan Jawa maupun di daerah lainnya di Indonesia. Aspek-aspek penting yang menjadi pertimbangan utama sebagaimana didiskusikan dalam tulisan ini adalah sbb:

- Kemampunan merekam data yang cukup rapat (di bawah 10 detik)

- Kemampuan mempertahankan kinerja yang baik dengan data terekam mencapai lebih dari 91\%

- Kemampuan transmisi data yang cepat kurang dari 25 detik dengan kemampuan mencapai 99\% dari total data yang terekam

- Kemampuan memberikan data gambar CCTV untuk mengkonfirmasi kejadian tsunami

- Kemampuan memberikan peringatan dini segera saat kejadian gempabumi yang mengakibatkan guncangan pada struktur stasiun pasang surut dan kerangka struktur IDSL/PUMMA

- Biaya modal dan operasional yang jauh lebih murah dari sistem lain guna menjamin keberlangsungan dari sistem peringatan dini tsunami.

Walaupun pemanfaatan alat sebagai peringatan dini tsunami dapat memperkuat kesiapsiagaan masyarakat pesisir dalam mitigasi bencana tsunami, kemampuan masyarakat dalam membaca lingkungan sekitar dan evakuasi mandiri merupakan hal terpenting yang perlu mendapat perhatian utama mengingat kejadian tsunami di Indonesia yang berpotensi sangat cepat tiba di garis pantai pasca kejadian gempa bumi (kurang dari 1 jam).

\section{UCAPAN TERIMA KASIH}

Tim penulis mengucapkan terimakasih yang sebesarbesarnya kepada Pusat Riset Kelautan - BRSDMKPKKP yang telah mendanai riset ini dengan anggaran DIPA 2019 dan 2020. Kami juga sangat berterima kasih kepada Dr. Alessandro Annunziato dan tim di JRC-EC, Dr. Gegar S. Prasetya dari Ikatan Ahli Tsunami Indonesia (IAtsI), BIG, BMKG, IOTIC/IOCUNESCO, Tim PIAMARI Pangandaran dan warga Pantai Batukaras Pangandaran atas kerjasama dan dukungannya pada penelitian ini.

\section{DAFTAR PUSTAKA}

Annunziato, A. (2015). Inexpensive Device for Sea Level Measurement. Science of Tsunami Hazards, 34(4), 199-210.

Annunziato, A., Galliano, D., \& Bonaita, M. (2016). IDSL Sea Level Measurement Devices, Technical report JRC-EC. doi:10.2788/470647.

Annunziato, A., Prasetya, G., \& Husrin, S. (2019). Anak Krakatau volcano emergency tsunami early warning system. Science of Tsunami Hazards, 38(2), 68-95

BMKG. (2010). InaTEWS Indonesia Tsunami Early Warning System Konsep dan Implementasi, link: https://www.gitews.org/tsunami-kit/ id/E2/sumber lainnya/InaTEW S\%20-\%20 Konsep\%20dan\%20Implementasi.pdf, diakses pada 23 April 2020

BMKG. (2019). Indonesian Master Plan for Tsunami Early Warning System and Inclusion of Atypical Tsunami, A keynote speech by the Head of BMKG, the International Symposium on the Lesson Learnt from the 2018 Tsunamis in Palu and Sunda Strait-Jakarta 2019.

Borrero, J. C., McAdoo, B., Jaffe, B., Dengler, L., Gelfenbaum, G., Higman, B., Hidayat, R., Moore, A., Kongko, W., Lukijanto, Peters, R., Prasetya, G., Trrov, V., \& Yulianto, E. (2011). Field Survey of the March 28, 2005 NiasSimeulue Earthquake and Tsunami. Pure and Applied Geophysics, 168(6), 1075-1088.

Borrero, J.C., Solihuddin, T., Fritz, H.M. et al. (2020). Field Survey and Numerical Modelling of the 
December 22, (2018). Anak Krakatau Tsunami. Pure Appl. Geophys. 177, 2457-2475. https:// doi.org/10.1007/s00024-020-02515-y

Fritz, HM., Kongko, W., Moore, A., McAdoo, B., Goff, J., Harbitz, C., Uslu, B., Kalligeris, N., Suteja, D., Kalsum, K., Titov, V., Gusman, A., Latief, H., Santoso, E., Sujoko, S., Djulkarnaen, D., Sunendar, H., \& Synolakis, C. (2007). Extreme runup from the 17 July 2006 Java tsunami. Geophysical Research Letters, 34(12), L12602. DOI: 10.1029/2007GL029404

Giachetti,T., Paris, R., Kelfoun, K., and Ontowirjo B (2012). Tsunami hazard related to a flank collapse of Anak Krakatau Volcano, Sunda Strait, Indonesia. Geological Society, London, Special Publications, 361, 79-90. https://doi. org/10.1144/SP361.7

Husrin, S., Azzahra, F. Y., Prihantono, J., Tussadiah, A., Abida, R. F. (2020a). Hydrodynamics of Palu Bay during the Event of 2018 Palu Earthquake and Tsunami. Bulletin of The Marine Geology, 35(1), 23-31. DOI: http://dx.doi.org/10.32693/ bomg.35.1.2020.658

Husrin, S., Fauzah, S., Safi'i, A. N., Patriabekti, Y. D. H. (2020b). Sistem Peringatan Dini Tsunami di Selat Sunda, dalam Bunga Rampai Mitigasi Bencana Selat Sunda, Editor (Solihuddin, et al), IPB Press.

Husrin. S., Kelvin. J., Putra. A., Prihantono. J., Yudhi Cara., Hani. A (2015). Assessment on the characteristics and the damping performance of coastal forests in Pangandaran after the 2006 Java Tsunami, Procedia Earth and Planetary Science, Volume 12, 2015, Pages 20-30, https:// doi.org/10.1016/j.proeps.2015.03.007

JRC-EC. (2019). Stromboli Volcano Eruption, July 3rd 2019, Emergency Response Coordination Centre (ERCC), DG ECHO Daily Map 04/07/2019, (diakses terakhir tanggal 29 Oktober 2020) link: https://www.gdacs.org/contentdata/maps/daily/ VO/211040/ECDM_20190704_Italy_Stromboli. pdf

Lauterjung, J., \& Letz, H. (Eds.) (2017). 10 Years Indonesian Tsunami Early Warning System: Experiences, Lessons Learned and Outlook, Potsdam: GFZ German Research Centre for
Geosciences, 68 p. DOI: http://doi.org/10.2312/ GFZ.7.1.2017.001

Lauterjung, J., Münch, U., \& Rudloff, A. (2010). The challenge of installing a tsunami early warning system in the vicinity of the Sunda Arc, Indonesia. Natural hazards Earth System Sciences, 10(4), 641-646.

Lavigne, F., Gomes, C., Giffo, M., Wassmer, P., Hoebreck, C., Mardiatno, D., Prioyono, J., \& Paris, R. (2007). Field Observation of the 17 July 2006 Tsunami in Java. Natural Hazards and Earth Systems Sciences, 7(1), 177-183.

Liu, P. L.-F., Higuera, P., Husrin, S., Prasetya, G. S., Prihantono, J., Diastomo, H., Gunawan, D., \& Susmoro, H. (2020). Coastal landslides in Palu Bay during 2018 Sulawesi Earthquake and Tsunami, Landslides (In Press).

Maramai, A., Graziani, L., \& Brizuela, B. (2019). EuroMediterranean Tsunami Catalogue (EMTC) (Version 2.0). Istituto Nazionale di Geofisica e Vulcanologia (INGV). https://doi.org/10.13127/ tsunami/emtc.2.0

Okal, E. A., (2012). The south of Java earthquake of 1921 September 11: a negative search for a large interplate thrust event at the Java Trench. Geophys. J. Int., 190(3), 1657-1672. DOI: 10.1111/j.1365-246X.2012.05570.x

Omira, R., Dogan, G. G., Hidayat, R., Husrin, S., Prasetya, G., Annunziato, A., Proietti, C., Probst, P., Paparo, M. A., Wronna, M., Zaytsev, A., Pronin, P., Giniyatullin, A., Putra, P. S., Hartanto, D., Ginanjar, G., Kongko, W., Pelinovsky, E., Yalciner, A. C., (2019). The September 28th, 2018, tsunami in Palu-Sulawesi, Indonesia: a post-event field survey. Pure Appl Geophys 176(4), 1379-1395. https://doi.org/10.1007/ s00024-019-02145-z

Wang, X. (2009). User Manual for Comcot Version 1.7 (First Draft). http://ceeserver.cee.cornell.edu/ pll-group/comcot_down.htm.

Williams R., Rowley, P., Garthwaite, M. C. (2019). Reconstructing the Anak Krakatau flank collapse that caused the December 2018 Indonesian Tsunami. Geology, 47(10), 973-976. 